\title{
“Do Not Weep” (Luke 7: 13): In the Footstep of the Compassionate Jesus
}

\author{
Mary Jerome Obiorah \\ Department of Religion and Cultural Studies, University of Nigeria, Nsukka, Nigeria \\ Email: mjchukwu@yahoo.co.uk
}

Received 20 May 2014; 27 June 2014; accepted 12 July 2014

Copyright (C) 2014 by author and Scientific Research Publishing Inc.

This work is licensed under the Creative Commons Attribution International License (CC BY). http://creativecommons.org/licenses/by/4.0/

(c) (i) Open Access

\section{Abstract}

The divine image, which every human being bears as a result of God's benevolence at creation, attracts us to the Divine. Human beings are religious by nature and in order to fully realise themselves as humans they have to be and live out the divine qualities instilled in each of them by the Creator. The opposite is often the case when human actions are critically evaluated. One of the divine qualities, which we ought to acquire and practice in order to enhance good human relationship, is compassion. This singular divine feature characterised Jesus earthly ministry in words and deeds. In this paper, the writer focuses on an episode in the life of Jesus, as recorded in the Gospel according to Luke $7: 11-17$. Jesus had compassion on the widow who lost her only son; he consoled and restored her son back to her. In following Jesus' footsteps we can make our world better and be able to bear and live with others.

\section{Keywords}

Compassion, Gospel According to Luke, Women, Widow, Nain

\section{Introduction}

Jesus still speaks to all who believe in him and in the Gospel narratives. In a world where violence has become a manifestation of supremacy and the oppressed languish in silence, his compassion towards a helpless widow, who has lost her only source of identity, poses a challenge to our society. The story of how Jesus raised the widow's son at the gate of Nain is from Luke's special source for it is found only in this Gospel (Luke 7: 11-17 see text below). In the entire Bible the name, Nain, occurs only in this narrative. The delimitation of the pericope creates no problem for there are some indications in the text that this narrative has an internal logic. In the preceding story (Luke 7: 1-10 see text below) Jesus was at Capernaum (Luke 7: 1), which is about twenty-five miles northeast of Nain. The characters in Luke 7: 1-10 comprise a centurion and his servant, the Jewish elders, 
and of course, Jesus and his disciples. In Luke 7: 11-17 two groups of persons, going on opposite directions, encounter each other at the gate of Nain. Each of these two distinct crowds has a central figure: for those entering the city, Jesus is the important character and for those exiting, the widow occupies a central position. The event narrated by Luke in 7: 11-17 is actually an encounter between these two protagonists: Jesus and the widow. Luke 7: 18-35 (see text below) has another subject matter different from the one that immediately precedes it. It is about Jesus' encounter with John's messengers.

The text on how Jesus raised the widow's son is a complete story in itself while it has some links with the two pericopes that flank it. When compared with the healing of a centurion's servant, the raising of an only child of a widowed mother accentuates the power of Jesus over death: he equally has authority over death. Disease and death are subject to Jesus' power. Again vv. 11-17 relate to vv. 18-35 particularly in the phrase "and the dead are raised" in vv. 22. The acclamation of the crowd, "God has looked favourably on his people" (v. 16), re-echoes the contents of v. 22. This can be compared with Luke 1: 68 that states: "Blessed be the Lord God of Israel, for he has looked favorably on his people and redeemed them". Similar text in the Old Testament is Psalm 111: 9: "He sent redemption to his people; he has commanded his covenant forever. Holy and awesome is his name". The raising of the widow's son stands as a concrete exemplification of these manifestations of the Messianic era (Fitzmyer, 1981; Hendrickx, 1998). A closer look at Luke 7: 11-17 shows that the narrator intends to portray Jesus as a compassionate miracle worker who was moved by the desperate condition of one of the less privileged of his contemporary society, a widow. It is also a lesson for all of us who today read this episode (Bradley, 2007; Clendenin, 2013).

\section{The Relevant Biblical Texts}

The relevant texts from the Gospel according to Luke are cited in the following paragraphs from the New Revised Standard Version of the Bible.

\subsection{Luke 7: 1-10}

${ }^{1}$ After Jesus had finished all his sayings in the hearing of the people, he entered Capernaum. ${ }^{2} \mathrm{~A}$ centurion there had a slave whom he valued highly, and who was ill and close to death. ${ }^{3}$ When he heard about Jesus, he sent some Jewish elders to him, asking him to come and heal his slave. ${ }^{4}$ When they came to Jesus, they appealed to him earnestly, saying, "He is worthy of having you do this for him, ${ }^{5}$ for he loves our people, and it is he who built our synagogue for us." ${ }^{6}$ And Jesus went with them, but when he was not far from the house, the centurion sent friends to say to him, "Lord, do not trouble yourself, for I am not worthy to have you come under my roof; ${ }^{7}$ therefore I did not presume to come to you. But only speak the word, and let my servant be healed. ${ }^{8}$ For I also am a man set under authority, with soldiers under me; and I say to one, 'Go,' and he goes, and to another, 'Come,' and he comes, and to my slave, 'Do this,' and the slave does it." ' When Jesus heard this he was amazed at him, and turning to the crowd that followed him, he said, "I tell you, not even in Israel have I found such faith.” ${ }^{10}$ When those who had been sent returned to the house, they found the slave in good health.

\subsection{Luke 7: 11-17}

${ }^{11}$ Soon afterwards he went to a town called Nain, and his disciples and a large crowd went with him. ${ }^{12}$ As he approached the gate of the town, a man who had died was being carried out. He was his mother's only son, and she was a widow; and with her was a large crowd from the town. ${ }^{13}$ When the Lord saw her, he had compassion for her and said to her, "Do not weep." ${ }^{14}$ Then he came forward and touched the bier, and the bearers stood still. And he said, "Young man, I say to you, rise!" ${ }^{15}$ The dead man sat up and began to speak, and Jesus gave him to his mother. ${ }^{16}$ Fear seized all of them; and they glorified God, saying, "A great prophet has risen among us!" and "God has looked favorably on his people!" ${ }^{17}$ This word about him spread throughout Judea and all the surrounding country.

\subsection{Luke 7: 18-35}

${ }^{18}$ The disciples of John reported all these things to him. So John summoned two of his disciples ${ }^{19}$ and sent them to the Lord to ask, "Are you the one who is to come, or are we to wait for another?" ${ }^{20}$ When the men had come to him, they said, "John the Baptist has sent us to you to ask, 'Are you the one who is to come, or are we to wait 
for another?'” ${ }^{21}$ Jesus had just then cured many people of diseases, plagues, and evil spirits, and had given sight to many who were blind. ${ }^{22}$ And he answered them, "Go and tell John what you have seen and heard: the blind receive their sight, the lame walk, the lepers are cleansed, the deaf hear, the dead are raised, the poor have good news brought to them. ${ }^{23}$ And blessed is anyone who takes no offense at me.” ${ }^{24}$ When John's messengers had gone, Jesus began to speak to the crowds about John: "What did you go out into the wilderness to look at? A reed shaken by the wind? ${ }^{25}$ What then did you go out to see? Someone dressed in soft robes? Look, those who put on fine clothing and live in luxury are in royal palaces. ${ }^{26}$ What then did you go out to see? A prophet? Yes, I tell you, and more than a prophet. ${ }^{27}$ This is the one about whom it is written, 'See, I am sending my messenger ahead of you, who will prepare your way before you. ${ }^{28}$ I tell you, among those born of women no one is greater than John; yet the least in the kingdom of God is greater than he." ${ }^{29}$ (And all the people who heard this, including the tax collectors, acknowledged the justice of God, because they had been baptized with John's baptism. ${ }^{30}$ But by refusing to be baptized by him, the Pharisees and the lawyers rejected God's purpose for themselves.) ${ }^{31}$ “'To what then will I compare the people of this generation, and what are they like? ${ }^{32}$ They are like children sitting in the marketplace and calling to one another, 'We played the flute for you, and you did not dance; we wailed, and you did not weep. ${ }^{33}$ For John the Baptist has come eating no bread and drinking no wine, and you say, 'He has a demon'; ${ }^{34}$ the Son of Man has come eating and drinking, and you say, 'Look, a glutton and a drunkard, a friend of tax collectors and sinners! ${ }^{35}$ Nevertheless, wisdom is vindicated by all her children."

\section{Jesus-The Benefactor of Widows}

At the first sight it might seem that the evangelist merely has it in mind to narrate the raising of a young man who was being carried out for burial. An attentive reading, however, manifests that the widowed mother is at the center of the narrative. It is a meeting between the two important persons of the two groups of people in the pericope; it is an encounter between Jesus and the widow. This story is told from the widow's point of view and the miracle is realized because of her. Other persons in her group are mentioned in relation to her. The dead man was her only son (monogenēs), and with her was a large crowd from the town. The term monogenès "only son" occurs three times in the Synoptic Gospels and only in Luke. Besides Luke 7: 12; the other occurrences are also in similar miracle stories (cf. Luke 8: 42 and 9: 38). According to the narrator, Jesus seems not to take notice of the crowd for his gaze was directed only to this poor woman and his first words at the sight of this crowd were addressed to her (v. 13); he had compassion for her. Furthermore, when the dead young man was raised, Jesus gave him back to the mother (v. 15). In fact, the widow occupies a central role in the text. "She represents another example of a group of those in need, widows who are among the most oppressed or neglected of society" (Kopas, 1986: p. 195).

It has been observed that Luke has special concern for widows (O'Toole, 1984). Widows were often dependent on the nearest of their male kin. At the time of Jesus, they were among the less privileged in the society and they suffered most from others. Actually, a woman was greatly linked to her male child who was a source of joy and security to her (Pilch, 1997; Sizer, 1999). In the same Gospel of Luke, the prophetess Anna, however, found a way out to this constraint. She lived her widowhood in the temple (Luke 2: 36-38). In a programmatic stage in Luke 4: 16-30, Jesus compared himself to the prophet Elijah who was sent to the widow of Zarephath in Sidon. At the time of the prophet, many were in need as they suffered the aftermath of the drought and consequent hunger. Only the poor widow was the beneficiary of the divine intervention through the prophet Elijah.

According to Luke-Acts, Jesus, the new Elijah, exhibits unprecedented concern for widows. A widow is depicted as a model of persistent prayer in Luke 18: 1-8 (Harris, 1991). This parable story in Luke 18: 1-8 conveys also the unacceptable condition of widows at the time of Jesus. Even those who should plead for their course neglected them. The judge in the parable was wearied by the poor widow before he could grant her request. Jesus reckons the persistence of the untiring widow as a virtue worthy of emulation. Furthermore, in Luke 21: 1-4 (cf. Mark 12: 41-44), a widow was praised for her generosity when she gave all she possessed. Her offering was unreserved unlike the offering of the rich who gave from the abundance of their wealth. The poor widow gave out of her poverty. Jesus condemned the attitude of the scribes who exploited widows (Luke 20: 47; cf. Mark 12: 40); he is the Saviour of the disadvantaged. In his concern for the widows, Jesus affirms the Law, which stipulates, "You shall not abuse any widow or orphan" (Exodus 22: 22). The triad, "alien, widow and orphan", occurs often in the dictates of the Law and the preaching of the prophets (cf. Deuteronomy 24: 20-21; 27: 19; Psalms 94: 6; 146: 9; Jeremiah 7: 6; 22: 3; Zechariah 7: 10 and Malachi 3: 5). These three are counted among the less privi- 
leged of the society for they have no one to speak for them. In the Old Testament God is presented as the Protector of the widows, orphans and strangers for he executes justice for the orphan and the widow, and loves the strangers, providing them food and clothing (Deuteronomy 10: 18). Therefore, in the life of Jesus, especially in his concern for the widows, there is continuity with the Old Testament account of God's tender care of the marginalized of the society.

In the Acts of the Apostles, the early followers of Jesus manifested similar concern for the plight of widows. A plan to make proper provision for the efficient caring of widows gave rise to the election of the seven trustworthy men who were entrusted with this task (Acts 6: 1-6). Dorcas was remembered for her special care of widows. When she died, Peter raised her to life and gave her back to the saints and widows (Acts 9: 36-42). The early Church was aware of the sufferings of widows and like Jesus the Christians did not overlook these less privileged members of the Church. In Luke 7: 11-17 the evangelist presents us with an impressive example of Jesus' attitude towards widows and towards all who are afflicted in life. The story embodies a characteristic of Jesus that is very dear to the author of the Third Gospel, compassion.

\section{Moved by Compassion}

Luke 7: 11-17 contains a miracle story for it has features similar to other miracle episodes in the gospels (Tiede 1988). The introductory part (vv. 11-12a) of the pericope presents a human interest in the scene: a dead man was being carried outside the gate for interment. Verses 12b-13a recount the afflicting condition of the bereaved mother. There is a dramatic encounter with Jesus, the healer (vv. 13b-14). In v.15 the effectiveness of the miracle is stated: the dead man shows signs of being alive; he sat up and began to communicate to those around. The mother received him back from Jesus. In vv. 16-17 the bystanders unanimously acclaim this as a miracle, a supernatural favour; God has visited his people.

In the core of this miracle story or resuscitation account, as some would like to classify it (Hendrickx, 1998), is a central message that can be educed from the text: the compassion of Jesus. The structure of this pericope runs as follows: there is, first, an introduction (v. 11); the encounter between Jesus' group and the funeral procession with an afflicted widow in the centre (v. 12); verse 13 contains the turning point in the story because it is here that the condition of the widow was significantly changed when Jesus said to her: "do not weep"; in vv. 14-15 the widowed mother received her only hope back; vv. 16-17 contain the aftermath of the story (Menken, 1988).

Verse 13 marks the turning point in the pericope. Both the preparatory scenes before this verse and the other verses that are subsequent to it are all centred on this change of fate in the life of the poor widow who encountered the Great Prophet acclaimed and pronounced so by the awe-stricken crowd. According to the Greek text of Luke 7: 11-17, the phrase "he had compassion for her" is preceded by one hundred and six (106) syllables and followed by one hundred and five (105) syllables. The whole story is made up of two hundred and eighteen (218) syllables (Menken, 1988). In other words, the phrase is in the middle of the narrative and it contains the interpretative key word of the story. This key word is compassion, to have compassion-splanchnizesthai "to be moved with pity or compassion, to have pity or compassion” (Abbot-Smith, 1999: p. 414; Bauer, 1979: p. 962). It corresponds to the Hebrew răham which designates a strong sentiment or emotion that moves one to action. Luke employs this verb only three times in his Gospel (cf. 7: 13; 10: 33 and 15: 30). In each of these texts, splanchnizesthai occupies a central position and signals a turning point in the account.

A survey of the use of the phrase, "to have compassion", in the New Testament reveals that "it is always used to describe the attitude of Jesus and it characterizes the divine nature of His acts” (Köster, 1995: p. 553). The sight of the poor widow and the large crowd of sympathizers generated within him the feeling that he expressed in the words: "Do not weep". This made a great change in the life of the widow. Compassion, especially with the verb that Luke employs in this passage, is reserved solely for similar attitude of Jesus to human needs, except when it occurs in the parable (cf. Luke 15: 30). A close reading of the parable shows that its interpretation and application are not far from Jesus' teaching on divine human relationship. In other words, it could be applied to Jesus or to the Father.

In Luke, besides the story of the widow of Nain, "to have compassion" features again in the story of the Good Samaritan (Luke 10: 25-37). A Samaritan traveller had pity on the ill-fated man who was left half dead by some brigands. Just like Jesus in 7: 11-17, the feeling of compassion exhibited by the Samaritan was followed by practical manifestation of love. He was moved to save the life of the man. Splanchnizesthai constitutes a decisive moment in the story. As in Luke 7: 11-17, this verb is again in the center of the narrative: the number of 
words that precede it is the same in proportion to the ones that follow. In other words, the account of the Good Samaritan is constructed in such a way that splanchnizesthai comes in the middle of the episode. The condition of the luckless man began to ameliorate when the Good Samaritan was moved with compassion. In this story, compassion is not a redundant emotion but a sentiment that moves someone to a beneficent action.

Another text in Luke where splanchnizesthai plays an important role in the teaching of Jesus is in the parable of the Prodigal Son, a text that is again from Luke's distinctive source (Luke 15: 11-32). Before the pitiable son could relay to his father his well-calculated words of apology, the father, just like Jesus in 7: 11-17, anticipated the need of his son and according to the narrator of the story: "But while he was still far off, his father saw him and was filled with compassion; he ran and put his arms around him and kissed him” (Luke 15: 20). The young man needed love and forgiveness, and his father was rich in both and was generous in giving. His gestures of love towards this young man stand in sharp contrast to the attitude of his elder son.

In the Gospel according to Luke, the noun splanchnon from splanchnizesthai occurs only once and in its plural form, splanchna in the Benedictus (cf. Luke 1: 78. It is also in the middle of the hymn but in its second part. The Benedictus (Luke 1: 68-79) is made up of two parts: Benediction (vv. 68-75) and prophecy addressed to the newly born child, John (vv. 76-79). Splanchna followed by a genitivus qualitatis (eleous) occurs in the middle of this second part.

In all these texts from Luke, the emphatic position of splanchnizesthai indicates the importance the author has accorded to the word. Therefore, the interpretation of these texts has to begin from this word. Although the story of the raising of a widow's son manifests features of a miracle, the evangelist presents Jesus as a compassionate benefactor of the grief-stricken woman rather than one who wrought prodigies. Other approaches to this text arrive at the same conclusion (Vogels, 1983).

\section{Reading the Story more Closely}

Luke 7: 1-17 presents a very striking example of a figure of speech in the Bible called polysyndeton-the repetition of many "and" at the beginning of successive clauses". This is a special form of anaphora-a repetition of the same word at the beginning of successive sentences. The direct opposite of what we have in our text is called asyndeton- - "no ands" or without conjunctions. Both polysyndeton and asyndeton have their significance when employed in a text. They intentionally violate the rule of grammar for the sake of emphasis for they are used in order to attract the attention of the hearer or the reader. Usually the conjunction "and" marks a climax when various components in a sentence are being stated or enumerated. In a text of "no ands", the writer invites the readers or hearers to hasten to the end. The phrase that contains "and" is the most important and it is this that the author accentuates. When "many ands" are used, every component is a climax on its own and in conjunction with other climaxes in the text. The reader or the hearer is expected to stop at each point and to reflect on each. In other words, every point mentioned is as important as the others. A careful reading of the pericope under consideration reveals no less than twenty "ands"; each of them introduces a fact for our earnest consideration (Bullinger, 2003). Hence we have a story that contains no superfluity; every phrase is dense in meaning. "The situation that Jesus encountered is sketched effectively so as to let us feel the full pathos of the scene” (Lenski, 1998: p. 397).

The story of Jesus' act of compassion, according to Luke 7, took place in the city or town of Nain. The Evangelist describes it as a polis "city, town". According to him, the town has a gate; it was probably walled like many ancient towns. Historians inform that what Luke describes as a polis was simply a village. In fact remains of its cemetery are still visible in the rocky area by the side of the road leading from Nain to the central trunk road (Aharoni, 2002). Nain is mentioned only here in the entire Bible and the rarity makes the story peculiar only to Luke. Today Nain is identified with the town of Nein in the plain of Jezreel on the north of modern Afula and it is about five miles southeast of Nazareth (Aharoni, 2002). The place must have been familiar to Jesus because it is not far from the vicinity where he spent most of his life. The situation of Nain at the time of Jesus has even been described as a "prosperous village surrounded by thriving olive and fig orchards, thanks to an abundant spring” (Oyin Abogunrin, 1998: p. 1391). He was in one of his preaching tours to the neighbourhood of this town. The event that changed the desperate situation of the poor widow took place at the gate of the city where the group of mourners that followed the woman met the enthusiastic listeners that crammed Jesus' itinerancy. Luke has to include the phrase "the gate of the town" for the dead were usually buried outside the town. There is on the eastern part of the present day Nain evidence of ancient cemetery, which probably served as burial ground (Strange, 1992). 
Most component parts in the story in some way have been arranged, with the help of polysyndeton, in such a way that the entire pericope is held together by one central thrust, compassion. It is about the dead whom the narrator identifies in the early part of the story (cf. v. 12) with a phrase, "the only son", and this does not disclose the age of the person. In v. 14 we are told that he was a youth, a young man. Another air of compassion in the story is that this young man was the only son of his mother and she was a widow. The fact that he was the only son explains the reason for the large crowd that followed the woman. His death drew a great number of sympathizers. "Weeping for an only child" calls to mind the mourning rite alluded to in Zechariah 12:10 where grief for an only child is considered as having a national character. In two other passages in Luke, the writer employs the motif of an only child to convey the focus of Jesus' miracle of healing. Jairus, the leader of the Synagogue begged Jesus to cure his only daughter (cf. Luke 8: 40-56). In Luke 9: 37-43, the boy with a demon is the only son of his parents. The occurrence of such expression in Luke draws attention to the depth of tragedy involved and the compassionate feature of Jesus' miracles. He brought succour to those who were in dire need. In the case of the only son of the Widow of Nain, the term "only" "stresses the strait in which the widowed mother has been put by the death of her only child, and incidentally her only means of support (Fitzmyer, 1981). The death of the only son of the widow of Nain was a heartbreak recognized as such by the large crowd of sympathizers that accompanied her.

The joyless fate of the widow ought to impel one to pity her and this was exactly what Jesus did. Jesus, who alone can overpower death's nullifying effects, offered the widow real comfort that no other person could afford (Bock, 1994). She had lost her husband and now she was without any male support in a patriarchal society (Karris, 1992). All these stirred Jesus' compassion and render the entire story highly vivid and Jesus' compassion is almost palpable.

The description of the fate of the widow of Nain in Luke 7: 12 prepares for her encounter with Jesus as narrated in v.13; he was moved to compassion. Unlike in the preceding pericope, the spontaneity of Jesus' compassion for the widow requires no expression of faith from her or from the sympathizers. In Luke 7: 1-10, the episode before the raising of the widow's son, Jesus praised the faith of the Centurion in these words: "I tell you, not even in Israel have I found such faith" (v. 9). The raising of the widow's son is unconditional. It was his action that elicits faith in the form of divine praise, which the witnesses proclaimed (Kodell, 1982). In this way he is like Yahweh in the Old Testament who is unconditionally compassionate. Jesus pitied her for what she was and not for what she could do. Her faith was not a prerequisite for the divine action. Again, she as a person was at the centre of the narrative. It is impressive to note the frequency of her personal pronoun, autē in vv. 12-13; these verses describe her meeting with Jesus. "The dead young man is resuscitated because of Jesus' sympathy for the man's widowed mother” (Roth, 1997: p. 172).

Jesus first spoke the consolatory and anticipatory words: "Do not weep". Bock (1994) notes a parallel between Jesus' reaction to the widow of Nain and John 11: 33. It was anticipatory because it prepared for the ensuing miracle. Jesus' succinct verbal expression "creates in the narrative, as an implied promise of action, a sense of anticipation" (Nolland, 1989: p. 324). His use of present imperative me klaie presupposes that the woman was pouring her heart in tears. He was actually telling her to stop crying. She must have heard similar consolatory words from those who commiserate with her but "only Jesus could say 'do not weep' and at the same time remove the cause of the tears" (Liefeld, 1995: p. 105). In Luke 8: 52, in a similar account of resuscitation story (Luke 8: 40-42, 49-56), Jesus prepares his miracle by pronouncing the same words addressed to a group of mourners.

Jesus, the compassionate benefactor of widows in the New Covenant, is called "the Lord” ho Kurios (v. 13). This is the first time the author of the Third Gospel recognizes him as the Lord and it is not without some significance in the present episode. Before the story in Luke 7: 11-17, Jesus has been addressed as ho Kurios but only as a respectful title (cf. Luke 5: 8, 12; 6: 46; 7: 6). In the Old Testament, ho Kurios is a frequent title of God who is the living God and the author of life. He is also the benefactor, defender, and patron of widows (cf. Exodus 22: 2-24). Ho Kurios of the New Testament has authority over life and death; just like the God in the Old Testament, Jesus is the defender of widows (Price, 1997). It is impressive to note that the evangelist predicates this divine title of Jesus just before He restored the young man to life. The Lord of life is able to give life back to the dead and he does this for the compassion he has for the widowed mother.

This was followed by unexpected gesture from him. It was unexpected especially when viewed from the perspective of the onlookers. He touched the bier (a stand on which a corpse is carried), thereby violating the dictates of Numbers 19: 11, 16: "Those who touch the dead body of any human being shall be unclean seven 
days". However, he had to go against this law of ritual purity because of his compassion for the poor widow. This calls to mind the story of the Good Samaritan. Those who would not like to breach the law of ritual purity were not stirred by the pitiable condition of the wounded man. A Samaritan is praised for his compassion, which was manifested in caring for the ill fated. Jesus knew the widow's son was dead and he touched the cortège.

Another gesture of Jesus that portrays compassion in the sentence is: "and Jesus gave him to his mother" (v. 15). The same phrase is found in the story of Elijah and the widow of Zarephath in 1 Kings 17:23. Actually the Septuagint of this Old Testament text corresponds verbatim to the phrase in Luke 7: 15. In a programmatic passage of Luke 4: 16-30, Jesus sees the encounter of this woman and Elijah as a prototype of his mission for he has been anointed to "bring the good news to the poor" (Luke 4: 18). Just as Elijah brought joy to the family of the widow in the OT, in the same way, Jesus turned the mourning of the widow of Nain and the whole town into joy.

Luke 7: 11-17 has some features parallels to a similar episode in the life of Prophet Elijah (cf. 1 Kings 17: 17-24). In both stories a widow is the beneficiary of the miracle (cf. 1 Kings 17: 9, 17). The death of an only son is seen in both stories. Just as Elijah met the widow at the gate of the town (1 Kings 17: 10), Jesus with his followers met the widow and her group at the gate of Nain (Luke 7: 12). The resuscitated sons of the widows in both stories show signs of revival; in Luke the young man began to speak (Luke 7: 15) and in the Elijah cycle the widow's son revived; "to speak" could be part of this revival (1 Kings 17: 22). The phrase edōken auton tē mêtri autou "he gave him to his mother" (1 Kings 17: 22; Luke 7: 15) features in both narratives. Jesus wrought the miracle for the sake of the widowed mother (Selvidge, 1987; Via, 1987; MacHaffie, 1988; Pilch, 1992). Furthermore, the exclamation of the astonished crowd in Luke 7:17 is reminiscent of the words of the widow in 1 Kings 17: 24.

Those who witnessed the miracle wrought by Jesus at the entrance to Nain recalled the great prophet of old. Jesus is the Great Prophet of their time: "A great prophet has risen among us", they exclaimed. The widow in 1 Kings 17: 17-24 made similar confession that sounds like an explicit protestation of faith: "Now I know that you are a man of God, and that the word of the Lord in your mouth is truth" (v. 24). The crowd, who witnessed what Jesus did, understood it as a sign of divine favour: "God has looked favorably on his people!” (v. 16). This also calls to mind the words of Zechariah in Luke 1:68 as well as the Old Testament text that Jesus read out in the Synagogue of Capernaum: “... to proclaim the year of the Lord's favour" (Luke 4: 19). Just as God was present to his people in the person of the prophet Elijah and the beneficiaries thus recognize and acclaim, Jesus' ministry as God's saving presence and tangible sign of God's favour to his people. The parallel between Jesus and Elijah in the Gospel of Luke, however, is more pronounced in Luke 9. Jesus is a prophet like Elijah but unlike Elijah he is ho Kurios who effortlessly wrought miracles.

Besides this parallel outside the Gospel of Luke, within the Gospel, Luke 7: 11-17 parallels 8: 40-56. In these two accounts we have an example of Luke's literary style whereby he generates doublets and parallels in order to achieve his theological purpose. Most of the doublets in Luke are "gender pairs". In the beginning of this Third Gospel, a heavenly message brought a message to Zechariah, the father of John the Baptist, and then to Mary, the Mother of Jesus. Both Zechariah and Mary sang a song of praise to God for the favour received from God (1: 46-55 and 68-79). Simeon and Anna both awaited the coming of the Messiah and the two met him in the temple. Other examples of such gender pairs abound in Luke's Gospel.

While a dead son is raised to life and given back to a grief-afflicted widow in Luke 7: 11-17, in 8: 40-56 it is a daughter that is restored to life for a father, Jarius. Luke's chiastic interchange (mother-son/father-daughter) in these two stories has this message to convey: Jesus' ministry favours all of God's creation; both genders are recipients of his compassion.

\section{In the Footstep of the Compassionate Jesus}

In the Biblical texts of Luke 7: 11-17, which we have analysed above, Jesus gave the widow of Nain what she was in dire need of: he restored her only son to life. In so doing, Jesus reinstated her in the society; because as a childless widow, especially without a male child, she no longer had voice in her society. It is instructive to observe that the initiative to do this came from Jesus; he did not wait for the poor childless widow to beg him before he performed this soothing miracle. Following the footstep of Jesus today, many of us may not be endowed with the supernatural gifts of raising a person from dead; however, we can, in various ways, like Jesus bring joy to the lives of many helpless persons. There are many who, like the widow of Nain, are desperately waiting for others to alleviate their sufferings. 
The world is not yet free of hunger in some countries; for there are many who hardly have enough of daily sustenance. A little sacrifice from the fluent is enough to sustain and keep this category of people alive so that they can live life worthy of human beings. They can be reached through some charitable organizations who work in various parts of the world. The hungry poor can also be helped to have permanent means of livelihood so that they may not be perpetually indigent.

There are others who are beset by sickness of various kinds and have no means of ridding themselves out of their situations. Some languish in their homes and have no ready helpers. These need the compassion of their fellow human beings for survival. In his public ministry, Jesus was particularly concerned about the sick; he made himself available to the consolation they needed from him; he touched them and healed them. Sometimes, he had no time for himself because of the huge crowd of those carrying their sick ones seeking for his healing touch. His selfless service gave them comfort and the healing they needed.

Many in our society are victims of unjust actions of those who intimidate and deprive them of their human rights. There are those who are unjustly accused and suffer for a long time in this degradation. Like the widow of Nain, they no longer have voice in their society. Such persons need the compassion of their fellow human beings who can liberate them from the unjust strings of the wicked.

Lack of formal education contributes adversely to the inhuman situations of many in various parts of the world. There are many who wallow in ignorance and are subjected to all kinds of social ills because they are not informed and they have no one to help inform them. Others cannot afford formal education because of poverty. They need the compassion of those who can help them live lives worthy of human beings. It is the task of every government, and all who have the means, to provide citizenry with adequate education for a better society. Jesus spent his life teaching his contemporaries. As an itinerant teacher, he went about teaching all who listened to him and his teaching made great impression on them for he did not teach like any of the teachers they knew. One of the things that distinguished him from them all was unconditional compassion he had for all, even for his enemies from whom he suffered excruciating and ignominious death.

\section{Conclusion}

The social setting at the time of the composition of the Third Gospel, that is the Gospel according to Luke, was behind his constant and many references to Jesus' encounter with women, the afflicted and children. In a society where women and children were not counted, Luke presents a Saviour who has come to give freedom to all, especially to those who were considered second-class citizens. Luke's Gospel is replete with such examples of Jesus' care for the sick, the afflicted, women and children. Many of his accounts are imbued with human sentiments. The resuscitation of the widow's son gives us a good example of this. In the story of how Jesus raised the widow's son and in other two texts (Luke 10: 33 and 15: 20) where the key verb, splanchnizesthai occurs, the evangelist presents a characteristic feature of the divine compassion displayed by Jesus. God's love is unconditional; no one merits his love for it is a free gift to all, especially those who are most in need of it: a widowed mother, the man wounded by brigands, and a son who has squandered his father's property.

Luke's many human stories, particularly 7: 11-17, call for more profound reflection and inculcation in our contemporary society. Many parts of the world are still plagued by sufferings of varied degrees and little is being done to alleviate them. A just distribution of the divinely endowed resources that we have can go a long way to satisfying the need of masses who pine away in sickness, isolation and abject poverty while their rich compatriots continue to enrich themselves.

While some women have started making effort to assert their human dignity and have their stand in the society, their conditions in different parts of the world are indeed appalling. Many widows still undergo utter inhuman treatments from those who will, like Jesus, whisper to them unconditionally and without affectation, "do not weep!”

\section{References}

Abbot-Smith, G. (1999). A Manual Greek Lexicon of the New Testament. Edinburgh: T \& T Clark.

Aharoni, Y., et al. (2002). The Bible Atlas. Jerusalem: Carta.

Bauer, W. (1979). A Greek-English Lexicon of the New Testament and Other Early Christian Literature. Chicago, London: The University of Chicago. 
Bock, D. L. (1994). Luke 1:1-9:50. Baker Exegetical Commentary on the New Testament, Grand Rapids, Michigan: Baker Books.

Bradley, M. (2007). The Relevance of the Story of the Widow of Nain for Today. http://www.overend-methodist.com/widow\%20of\%20Nain.htm

Bullinger, E. W. (2003). Figures of Speech Used in the Bible Explained and Illustrated. Grand Rapids, Michigan: Baker Book House.

Clendenin, D. (2013). Jesus and the Widow of Nain. http://www.journeywithjesus.net/Essays/20130603JJ.shtml

Fitzmyer, J. A. (1981). The Gospel According to Luke I-IX. Anchor Bible 28, New York: Doubleday.

Harris, X. (1991). Ministering Women in the Gospel. In The Bible Today 29 (p. 111). Collegeville: The Liturgical Press.

Hendrickx, H. (1998). The Third Gospel for the Third World (Vol. 2: B). Ministry in Galilee (Luke 7, 1-9, 50), Collegeville, MN: A Michael Glazier Book, the Liturgical Press.

Karris, R. J. (1992). The Gospel According to Luke. In The New Jerome Biblical Commentary (pp. 675-721). London: Geoffrey Chapman.

Kodell, J. (1982). The Gospel According to Luke. Collegeville Bible Commentary New Testament Vol.3, Collegeville, MN: The Liturgical Press.

Kopas, J. (1986). Jesus and Women: Luke’s Gospel”, Theology Today, 43, 195.

Köster, H. (1995). Splanchnizomai. Theological Dictionary of the New Testament (Vol. 7: pp. 548-559). Grand Rapids, MI: Eerdmans.

Lenski, R. C. N. (1998). The Interpretation of St. Luke's Gospel. Commentary on the New Testament, Hendrickson.

Liefeld, W. L. (1995). Luke: The Expositor's Bible Commentary. Grand Rapids Michigan, Zondervan Publishing House.

MacHaffie, B. J. (1988). Her Story: Women in Christian Tradition. Philadelphia, PA: Fortress Press.

Menken, M. J. J. (1988). The Position of splangnizesthai and splagchna in the Gospel of Luke. In Novum Testamentum 30 (pp. 109-110). Leiden: Brill.

Nolland, J. (1989). Luke 1-9:20. Word Biblical Commentary Vol. 35A, Dallas, TX: Word Books.

O’Toole, R. (1984). The Unity of Luke's Theology: An Analysis of Luke-Acts. Wilmington, DE: Michael Glazier.

Oyin Abogunrin, S. (1998). Luke. In The International Bible Commentary, A Catholic and Ecumenical Commentary for the Twenty-First Century (pp. 1368-1437). Collegeville, MN: The Liturgical Press.

Pilch, J. J. (1992). Sickness and Healing in Luke-Acts. In Social World of Luke-Acts (p. 195). Peabody, MA: Hendrickson.

Pilch, J. J. (1997). The Cultural World of Jesus: Sunday by Sunday, Cycle C. Collegeville, PA: The Liturgical Press.

Price, R. M. (1997). The Widow Traditions in Luke-Acts: A Feminist-critical Scrutiny. Alpharetta, GA: Society of Biblical Literature.

Roth, S. J. (1997). The Blind, the Lame, and the Poor: Character Types in Luke-Acts. Sheffield: Sheffield Academic Press.

Selvidge, M. J. (1987). Daughters of Jerusalem. Scottsdale, PA: Herald Press.

Sizer, P. (1999). The Widow of Nain. http://www.orthodoxresearchinstitute.org/resources/sermons/sizer widow naian.htm

Strange, J. F. (1992). Nain. In Anchor Bible Dictionary (Vol. 4: pp. 1000-1001). London: Doubleday.

The Holy Bible: The New Revised Standard Version Catholic Edition (pp. 65-66) (1993). Bangalore: Theological Publications in India.

Tiede, D. L. (1988). Luke: Augsburg Commentary on the New Testament. Minneapolis, MN: Augsburg Publishing House.

Via, E. J. (1987). Women in the Gospel of Luke. In Women in the World's Religions, Past and Present (p. 42). New York: Paragon House.

Vogels, W. (1983). A Semiotic Study of Luke 7:11-17. In Eglise et Théologie (Vol. 14: pp. 273-292). Ottawa: Faculté de Théologie, Université Saint-Paul. 
Scientific Research Publishing (SCIRP) is one of the largest Open Access journal publishers. It is currently publishing more than 200 open access, online, peer-reviewed journals covering a wide range of academic disciplines. SCIRP serves the worldwide academic communities and contributes to the progress and application of science with its publication.

Other selected journals from SCIRP are listed as below. Submit your manuscript to us via either submit@scirp.org or Online Submission Portal.
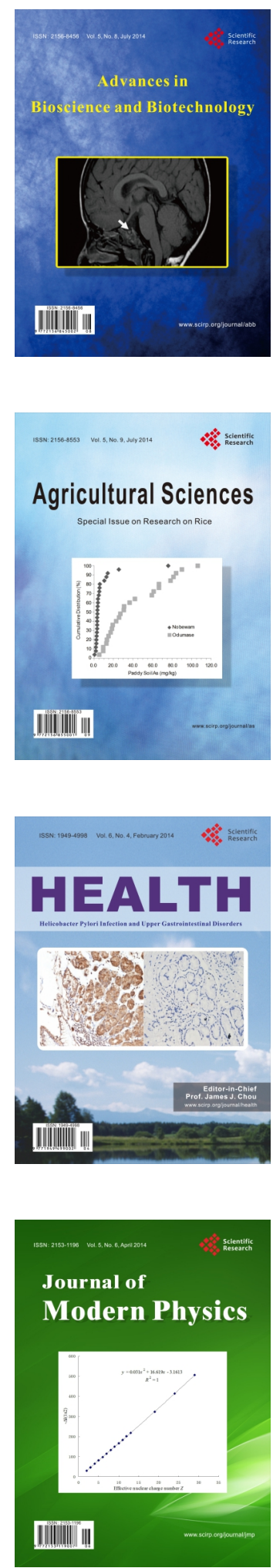
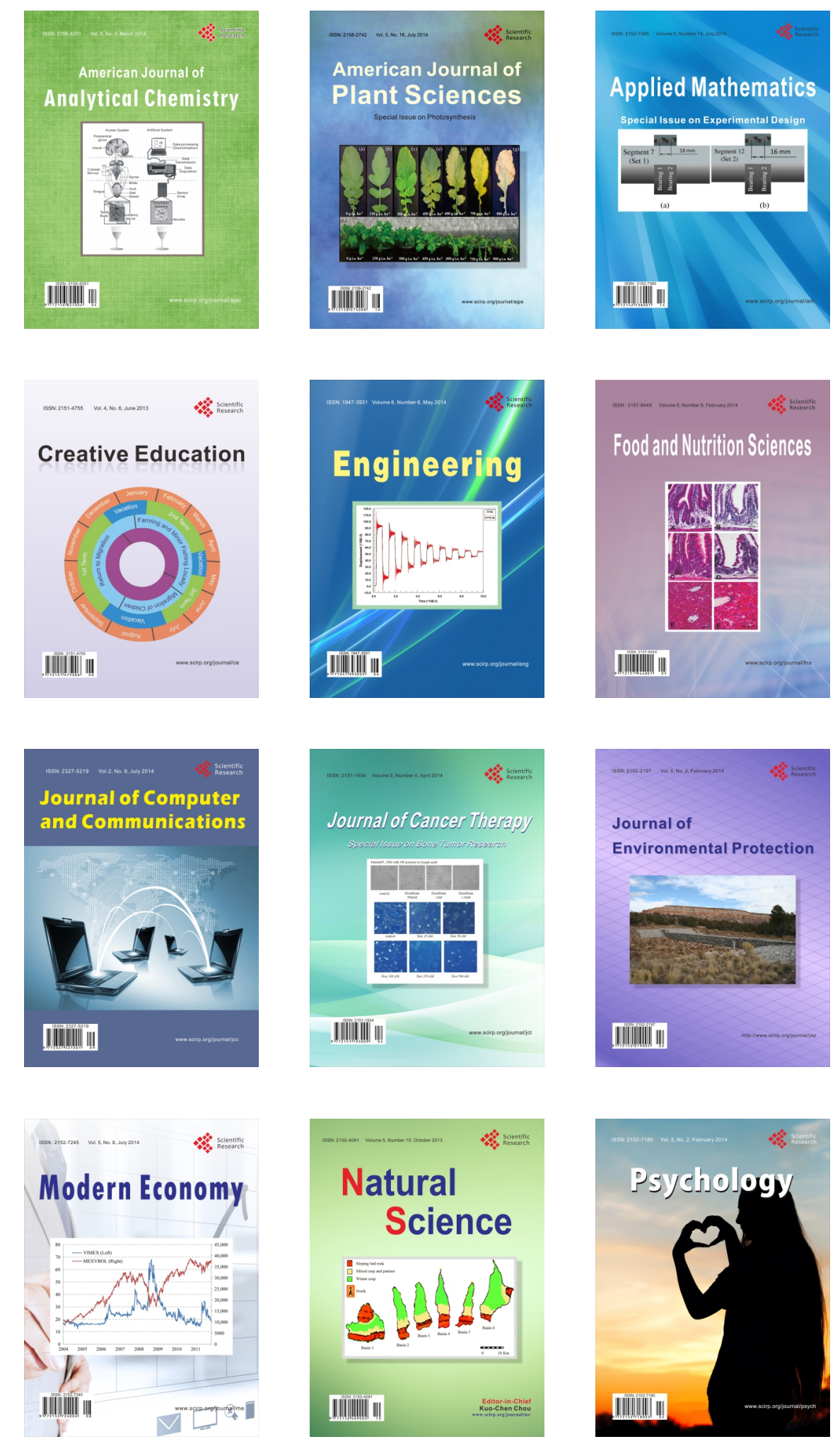